Бобиль В. В.

доктор економ. наук, доцент Дніпропетровський національний університет залізничного транспорту імені академіка В. Лазаряна

\title{
ІДЕНТИФІКАЦІЯ, ОЦНКА, ПЛАНУВАННЯ ТА ЗНИЖЕННЯ ФІНАНСОВИХ РИЗИКІВ ЗА ЦЕНТРАМИ ВІДПОВІДАЛЬНОСТІ БАНКУ
}

\author{
ИДЕНТИФИКАЦИЯ, ОЦЕНКА, ПЛАНИРОВАНИЕ И СНИЖЕНИЕ \\ ФИНАНСОВЫХ РИСКОВ ПО ЦЕНТРАМ ОТВЕТСТВЕННОСТИ БАНКА
}

\section{IDENTIFICATION, EVALUATION, PLANNING AND REDUCE THE FINANCIAL RISKS FOR THE CENTER RESPONSIBILITY OF BANK}

У статті розглянуто критерії виокремлення центрів відповідальності в сучасних банках Украӥни. Наведено характеристики груп банківських ризиків (фінансові, операџійні, функиіональні) та видів фінансових ризиків (кредитний, ринковий, ліквідності), які виникають у процесі здійснення активних та пасивних операцій банку. В досліджені послідовно розглянуто основні етапи управління фінансовими ризиками: ідентифікація, оцінка, планування, зниження. Проведено порівняльний аналіз методів оцінки (стратегічні, експертні, аналітичні, комбіновані) та інструментів зменшення розміру фінансових ризиків (страхування, хеджування, ліміти, диверсифікачія, резерви) за иентрами відповідальності банку. Розглянуто механізм розподілу ресурсів між цеентрами відповідальності банку, який також є одним з інструментів управління ринковим ризиком та ризиком ліквідності. Досліджено алгоритм стратегічного і фінансового планування господарської діяльності банку у якості складової управління фінансовими ризиками банку. Обтрунтовано необхідність подальшого удосконалення інструментів та методів ідентифікаџіï, оцінки, планування та зниження фінансових ризиків за иентрами відповідальності банку.

Ключові слова: банк, фінансові ризики, центри відповідальності, інструменти зменшення ризиків, планування, оцінка, ідентифікація, трансфертне ціноутворення.

В статье рассмотрень критерии выделения центров ответственности в современных банках Украины. Приведены характеристики групп банковских рисков (финансовые, операционнье, функциональные) и видов финансовых рисков (кредитный, рыночный, ликвидности), которые возникают в процессе осуществления активных $u$ пассивных операций банка. В исследовании последовательно рассмотрены основные этапь управления финансовыми рисками: идентификация, оценка, планирование, уменьшение. Проведен сравнительньий анализ методов оценки (стратегические, экспертные, аналитические, комбинированные) и инструментов уменьшения величины финансовых рисков (страхование, хеджирование, лимиты, диверсификация, резервы) по иентрам ответственности банка. Рассмотрен механизм распределения ресурсов между ичентрами ответственности банка, который также является одним из инструментов управления рыночным риском и риском ликвидности. Исследован алгоритм стратегического $u$ финансового планирования хозяйственной деятельности банка в качестве составляющей управления финансовыми рисками банка. Обоснована необходимость дальнейшего усовершенствования инструментов и методов идентификации, оценки, планирования $и$ снижения финансовых рисков по иентрам ответственности банка.

Ключевые слова: банк, финансовые риски, центры ответственности, инструменты снижения рисков, планирование, оценка, идентификация, трансфертное ценообразование. 
The article describes the criteria for allocation of responsibility centres in modern Ukrainian banks. Investigation the characteristics of bank risk (financial, operational, functional) and the types of financial risks (credit, market, liquidity), which arise in the implementation of active and passive operations of the bank. The study describes the main stages of the series of financial risk management: identification, assessment, planning, reduction. A comparative analysis of assessment methods (strategic, expert, analytical, combined) and tools reduce the amount of financial risks (insurance, hedging, limits, diversification and reserves) on the centres of the bank's liability. Considered resource allocation mechanism between the centres of the bank's responsibility, which is also one of the management tool of market risk and liquidity risk. The algorithm of strategic and financial planning business activities of the bank as a management component of the bank's financial risks. The necessity of further improvement of tools and methods to identify, assess, plan and reduce the financial risks on the centres of the bank's liability.

Keywords: banks, financial risks, responsibility centres, reduce risk tools, planning, assessment, identification, transfer pricing.

Вступ. В сучасних умовах посилення економічної нестабільності винятково важливого значення набуває проблема забезпечення фінансової стійкості банківської системи України. При цьому головною складовою розвитку банківських установ в ординарних та в кризових умовах $\epsilon$ ефективна система управління фінансовими ризиками.

Теоретичні, методологічні та методичні аспекти управління ризиками банку розглянуто в роботах провідних вітчизняних та зарубіжних вчених. Характеристику та класифікацію банківських ризиків подано у працях С. Брайонович-Братанович, Х. Ван Грюнінга, І. Д'яконової, І. Івасіва, П. Роуза, О. Ю. Фуксмана [1-4]. Перспективи розвитку інструментів та методів управління фінансовими ризиками визначили Т. Болгар, В. Вовк, В. Коваленко, Т. Косова, Є. Поздняков, Л. Примостка [5-8].

За наявності значної кількості досліджень, зазначимо, що проблематиці виокремлення центрів відповідальності банку та управління фінансовими ризиками (ідентифікація, оцінка, планування, зниження) за цими центрами приділяється недостатньо уваги, а це, у свою чергу, негативно впливає на фінансову стійкість сучасного банківського сектору України.

Постановка завдання. Метою статті $\epsilon$ визначення критеріїв виокремлення центрів відповідальності банку та дослідження інструментів та методів ідентифікації, оцінки, планування та зниження фінансових ризиків за центрами відповідальності.

Методологія. Для досягнення поставленої мети в процесі дослідження використано загальнонаукові (аналіз, синтез, індукція, дедукція) та спеціальні (спостереження, порівняння, розробка таблиць та рисунків) методи дослідження.

Результати дослідження. У статті під категорією «банківський ризик» розуміється ймовірність відхилення від запланованих (очікуваних) показників діяльності банку через здійснення активно-пасивних операцій, їх організацію, стан корпоративного управління та вплив факторів зовнішнього середовища, наслідки якої_можуть бути негативними, нульовими або позитивними. 
3 цього визначення виводяться групи банківських ризиків, а саме:

- фінансові ризики, що виникають у процесі здійснення активних та пасивних операцій банку;

- операційні ризики, які пов язані 3 організацією активно-пасивних операцій та станом корпоративного управління банку;

- функціональні ризики, що виникають через вплив факторів зовнішнього середовища банку.

До фінансових ризиків належать:

1. Кредитний - ймовірність відхилення від запланованих (очікуваних) показників через невиконання позичальником зобов'язань перед банком. Кредитний ризик доцільно розділяти на індивідуальний (конкретний контрагент банку) та портфельний (сукупна заборгованість) ризики.

2. Ризик ліквідності - ймовірність відхилення від запланованих показників через втрату збалансованості між активами і пасивами банку (балансовий ризик) та нездатність залучити фінансові ресурси для реалізації стратегічних цілей розвитку (ризик ліквідності ринку).

3. Ринковий ризик - ймовірність відхилення від запланованих показників через зміну валютних курсів, процентних ставок або вартості цінних паперів та інших активів. До складових ринкового ризику належать валютний, процентний та фондовий ризики.

Управління фінансовими ризиками банку складається 3 таких етапів: ідентифікація, оцінка, планування, зниження.

Ідентифікацію (виявлення) фінансових ризиків доцільно здійснювати за центрами відповідальності банку, під якими розуміються елементи банку (бізнес-напрямки), у межах яких встановлено особисту відповідальність їх керівників за виконання запланованих показників діяльності та рівень ефективності управління фінансовими ризиками, які вони контролюють.

Отже, для виокремлення «центра відповідальності» використовуються два критерії: бізнес-напрямок та вид фінансового ризику. Виділені за цими критеріями основні «центри відповідальності» наведено в таблиці 1.

Таблиця 1

Основні центри відповідальності банку*

\begin{tabular}{|c|c|c|}
\hline $\begin{array}{c}\text { Назва центра } \\
\text { відповідальності }\end{array}$ & Бізнес-напрями & $\begin{array}{c}\text { Види фінансових } \\
\text { ризиків }\end{array}$ \\
\hline Казначейство & $\begin{array}{l}\text { Оптимізація та регулювання грошових потоків } \\
\text { банку, купівля та продаж валюти для клієнтів і } \\
\text { власних потреб на міжбанківському ринку } \\
\text { України, залучення та розміщення коштів на } \\
\text { міжбанківському ринку України та міжнародних } \\
\text { ринках }\end{array}$ & $\begin{array}{l}\text { Ризик ліквідності, } \\
\text { ринковий ризик }\end{array}$ \\
\hline $\begin{array}{l}\text { Управління } \\
\text { корпоративного } \\
\text { бізнесу (УКБ) } \\
\end{array}$ & $\begin{array}{l}\text { Надання клієнтам широкого спектру послуг із } \\
\text { кредитування, за операціями } 3 \text { векселями, } \\
\text { залучення коштів юридичних осіб }\end{array}$ & $\begin{array}{l}\text { Кредитний, } \\
\text { ринковий ризик }\end{array}$ \\
\hline $\begin{array}{l}\text { Управління } \\
\text { індивідуального } \\
\text { бізнесу (УІБ) }\end{array}$ & $\begin{array}{l}\text { Продаж банківських продуктів індивідуальним } \\
\text { клієнтам банку, оптимізація вартості послуг для } \\
\text { фізичних осіб }\end{array}$ & $\begin{array}{l}\text { Кредитний, } \\
\text { ринковий ризик }\end{array}$ \\
\hline Управління цінними & Емісія власних цінних паперів, організація & Ринковий ризик \\
\hline
\end{tabular}




\begin{tabular}{|c|c|c|}
\hline $\begin{array}{l}\text { паперами } \\
\text { (інвестиційний } \\
\text { бізнес) (УЦП) }\end{array}$ & $\begin{array}{l}\text { купівлі та продажу цінних паперів за дорученням } \\
\text { клієнтів, здійснення операцій на ринку цінних } \\
\text { паперів від свого імені, андерайтинг, } \\
\text { інвестування у статутні фонди та цінні папери } \\
\text { юридичних осіб, довірче управління коштами та } \\
\text { цінними паперами за договорами з юридичними } \\
\text { та фізичними особами }\end{array}$ & \\
\hline Філіали & $\begin{array}{l}\text { Основним напрямами діяльності } є \text { банківські } \\
\text { операції, визначені письмовим дозволом у межах } \\
\text { наданих повноважень }\end{array}$ & $\begin{array}{l}\text { Кредитний, } \\
\text { ринковий, } \\
\text { ризик ліквідності }\end{array}$ \\
\hline
\end{tabular}

* побудовано автором

Розподіл фінансових ресурсів між центрами відповідальності здійснюється за допомогою трансфертної ціни, яка також $є$ одним 3 інструментів управління ринковим ризиком та ризиком ліквідності.

Головним завданням трансфертного ціноутворення $\epsilon$ : розрахунок та оцінка ефективності діяльності за центрами відповідальності, виходячи 3 фактичної вартості та прибутковості залучених та розміщених ресурсів; управління поточною ліквідністю банку та ринковим ризиком; управління GAP-розривами шляхом виконання операцій на міжбанківському ринку; оптимізація джерел фінансування активних операцій у центрах відповідальності банку.

Трансфертні ціни залучення та розміщення ресурсів розраховуються казначейством у момент купівлі-продажу ресурсів 3 урахуванням цілей управління ліквідністю (рисунок 1).

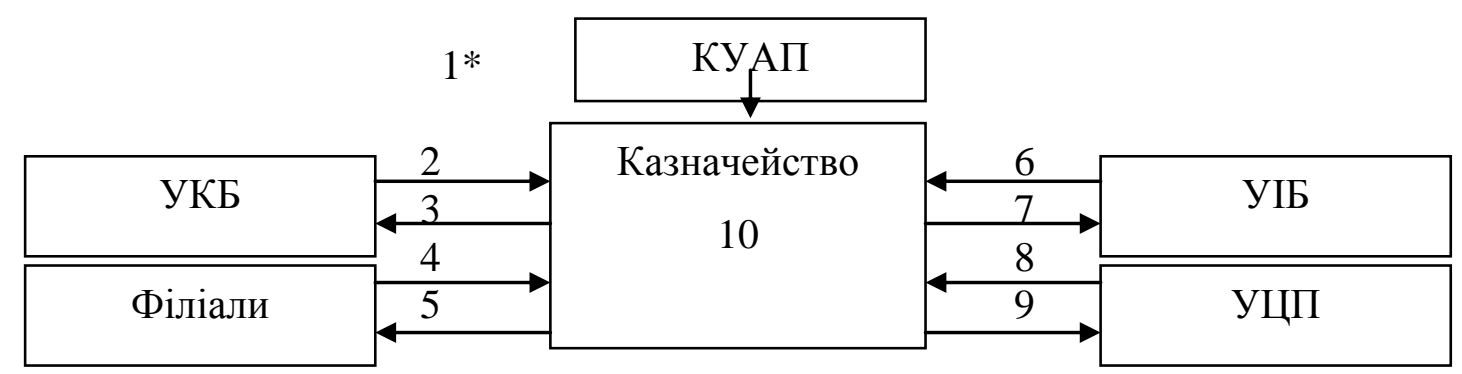

Рис. 1. Механізм перерозподілу фінансових ресурсів між центрами відповідальності банку (побудовано автором)

*Примітка: 1- встановлення граничних розмірів маржі (мінімальне і максимальне значення); 2 - продаж строкових пасивів юридичних осіб та коштів на розрахункових $\mathrm{i}$ поточних рахунках; 3 - купівля ресурсів для кредитування корпоративних клієнтів; 4 продаж депозитів; 5 - покупка фінансування для проведення активних операцій; 6 - продаж депозитів фізичних осіб, залишків на карткових рахунках; 7 - купівля ресурсів для кредитування фізичних осіб; 8 - продаж ресурсів від реалізації чи розміщення цінних паперів; 9 - покупка фондів для інвестування в цінні папери; 10 - покупка-продаж ресурсів за трансфертними цінами.

Центри відповідальності, що залучають ресурси (наприклад, філії), отримують прибуток, якщо доходи за продані казначейству ресурси перевищують витрати сегмента із залучення цих ресурсів (обслуговування депозитів) та їх накладні витрати.

Центри відповідальності, що розміщують ресурси (наприклад, УКБ), мають прибуток у тому випадку, якщо доходи від активних операцій 
покривають видатки сегмента, у тому числі і плату за отримані від казначейства ресурси. Так, прибуток УКБ визначається як дохід за наданими кредитами плюс трансферні ціни за строковими і поточними рахунками юридичних осіб, за винятком трансферних цін 3 фінансування кредитів і фактичних витрат сегмента.

Казначейство отримує прибуток від перерозподілу ресурсів у тому випадку, коли трансфертні ціни 3 фінансування активних операцій банку перевищують трансферні ціни залучення ресурсів і покривають власні витрати.

Як зазначалося раніше, керівник центру відповідальності має звітувати не тільки за дієвість управління фінансовими ризиками, а й за виконання запланованих показників діяльності свого центру.

Стратегічне та фінансове планування $є$ невід'ємною частиною системи управління фінансовими ризиками тому, що в основі поняття «банківський ризик» присутня ймовірність відхилення від запланованих економікофінансових показників діяльності банку.

Основне завдання стратегічного планування полягає в підвищенні гнучкості функціонування банківської організації в кризових та в ординарних умовах банку через визначення місії банку, стратегічних цілей його розвитку, сегментної орієнтації та ідентифікацію фінансових ризиків.

Основні проблеми в процесі формування та виконання стратегічного плану банку можуть виникнути у випадку реалізації корпоративного ризику (ймовірність відхилення від запланованих показників через помилки в корпоративному управлінні (конфлікт інтересів, помилки у визначенні бізнеспроцесів, розподілу функціональних обов язків тощо) або стратегічного ризику (ймовірність відхилення від запланованих показників через неадекватне реагування на зміни в бізнес-середовищі банку).

3 метою зниження величини цих ризиків стратегічний план банку рекомендується пов 'язати з відповідним бюджетним планом (приблизний обсяг фінансових ресурсів, необхідних для реалізації стратегічного плану банку).

На думку експертів, існують наступні принципи бюджетного процесу в банку [9]:

1. Взаємозв'язок стратегії i тактики. Бюджетування є інструментом реалізації стратегічного плану кредитної установи і представляє сукупність взаємопов'язаних елементів, що дозволяє підвищувати ефективність роботи банку в ординарних та в кризових умовах.

2. Багаторівневість. Цілісність бюджетної системи, що забезпечує єдина політика банку.

3. Безперервність. При складання бюджетів банку необхідно своєчасно та ефективно враховувати зміни чинників зовнішнього та внутрішнього середовища.

4. Багатоваріантність. Використання ситуаційної складової в процесі розробки бюджетів.

5. Ітераційне планування. Багаторазове узгодження бюджету в центрах відповідальності банку. 
6. Стандартизація. Уніфікація форматів бюджетів для центрів відповідальності банку.

7. Ефективність. У процесі складання бюджетів усі центри відповідальності повинні орієнтуватися на виконанні стратегічного плану банку при використанні визначеного бюджетом обсягу коштів.

8. Забезпечення єдності концептуальної схеми планування «зверху вниз» та «знизу вверх». Цей принцип дозволяє максимально задіяти всі центри відповідальності банку та розподілити відповідальність за досягнення результатів (у тому числі в питанні управління фінансовими ризиками).

Деякі банки для збільшення ефективності процесу бюджетування та управління фінансовими ризиками створюють бюджетні комітети (функціональний орган, що забезпечує розробку й узгодження бюджетів).

До функцій бюджетного комітету відносяться: 1. Вибір методів бюджетування; 2. Схвалення бюджетів; 3. Контроль за розробкою бюджетів керівниками центрів відповідальності; 4 Перегляд бюджетних оцінок; 5. Планування розміру фінансових ризиків, які пов язані 3 активно-пасивними операціями банку.

До складу бюджетного комітету зазвичай входить голова банку і його заступники, керівники центрів відповідальності, представники аналітичних відділів і ризик-менеджери.

Як зазначалося раніше, з метою підвищення ефективності стратегічного та бюджетного планування потрібно враховувати пропозиції начальників центрів відповідальності банку (процес планування в банку представлено на рисунку 2).

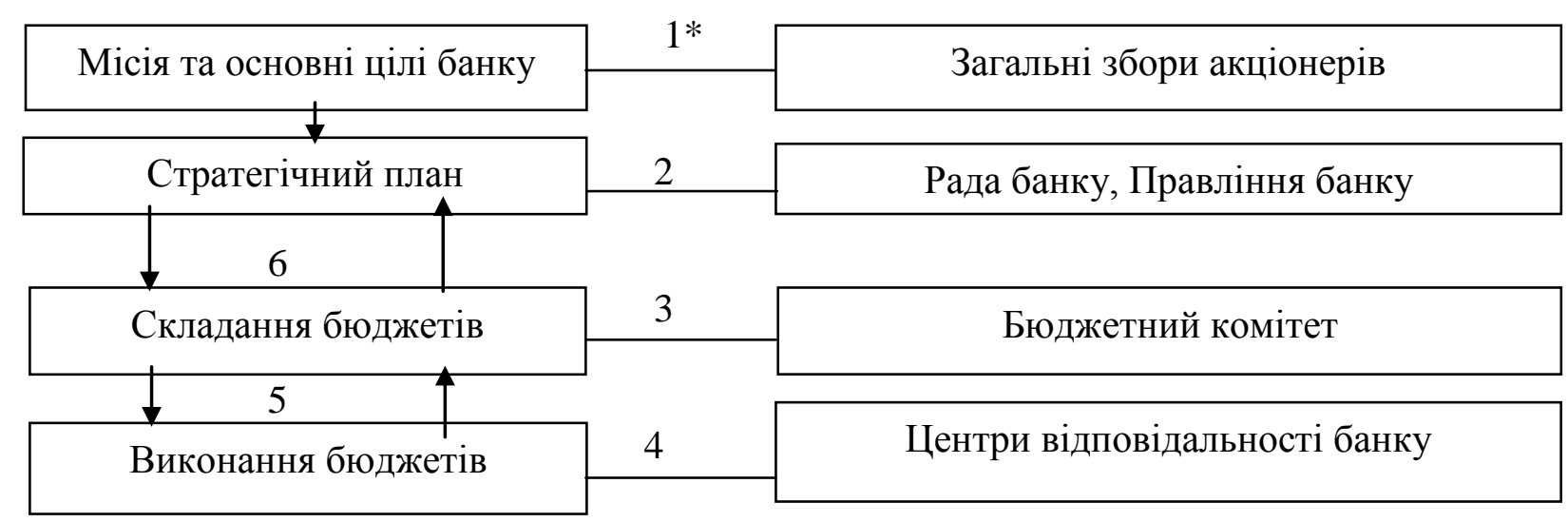

Рис. 2. Етапи стратегічного та бюджетного планування в банку (побудовано автором)

*Примітка:1. Затвердження місії й основних цілей банку на Загальних зборах акціонерів. 2. Складання стратегічного плану правлінням банку, затвердження і контроль за виконанням закріплюється за радою банку. 3. На основі стратегічного плану розробка бюджетів Бюджетним комітетом банку. 4. Виконання бюджету начальниками центрів відповідальності. 5. Пропозиції щодо зміни бюджетних позицій і звіт про виконання бюджетів перед Бюджетним комітетом. 6. Пропозиції щодо корегування стратегічного плану і звіт про його виконання.

Зазначимо, що при виконанні стратегічних планів та бюджетів необхідно враховувати вплив фінансових ризиків, які можуть негативно позначитися на 
реалізації запланованих показників діяльності банку. Для оцінки розміру фінансових ризиків банки використовують стратегічні, експертні, аналітичні та комбіновані методи оцінки (табл. 2).

Таблиця 2

Методи оцінки фінансових ризиків банку*

\begin{tabular}{|c|c|c|c|}
\hline Методи & $\begin{array}{l}\text { Вид фінансового } \\
\text { ризику }\end{array}$ & Переваги методу & Недоліки методу \\
\hline 1. Статистичні методи: & \multirow{5}{*}{ Кредитний } & \multirow{6}{*}{$\begin{array}{l}\text { Досить високе } \\
\text { визначення } \\
\text { розмірів збитку і } \\
\text { ймовірність їх } \\
\text { настання в } \\
\text { майбутньому в } \\
\text { ординарних } \\
\text { умовах }\end{array}$} & \multirow{6}{*}{$\begin{array}{l}\text { Необхідність } \\
\text { обробки великого } \\
\text { обсягу } \\
\text { статистичної } \\
\text { інформації. Мала } \\
\text { ефективність в } \\
\text { умовах кризи }\end{array}$} \\
\hline 1.1 Метод «Монте-Карло» & & & \\
\hline 1.2 Z-модель Альтмана & & & \\
\hline 1.3 Модель Чесера & & & \\
\hline 1.4 Модель Дюрана & & & \\
\hline $1.5 \mathrm{VaR}-$ метод & $\begin{array}{l}\text { Кредитний, } \\
\text { ринковий }\end{array}$ & & \\
\hline $\begin{array}{l}\text { 2. Методи експертних } \\
\text { оцінок: } \\
\text { Метод Дельфі }\end{array}$ & \multirow[t]{2}{*}{$\begin{array}{c}\text { Кредитний, } \\
\text { ринковий }\end{array}$} & \multirow{4}{*}{$\begin{array}{l}\text { Ефективний при } \\
\text { відсутності } \\
\text { достовірної } \\
\text { інформації чи їі } \\
\text { недостатності. } \\
\text { Висока } \\
\text { ефективність в } \\
\text { умовах кризи }\end{array}$} & \multirow[t]{4}{*}{$\begin{array}{l}\text { Суб'єктивний } \\
\text { характер. }\end{array}$} \\
\hline 2.1 Метод «дерева рішень» & & & \\
\hline $\begin{array}{l}2.2 \text { Метод коефіцієнтного } \\
\text { аналізу }\end{array}$ & \multirow[t]{2}{*}{ Кредитний } & & \\
\hline 2.3 Метод рейтингів & & & \\
\hline $\begin{array}{l}\text { 3. Аналітичні методи: } \\
3.1 \text { Дюрація }\end{array}$ & \multirow[t]{2}{*}{ Ринковий } & \multirow{3}{*}{$\begin{array}{ll}\text { Містить у собі } \\
\text { можливості } \\
\text { факторного } \\
\text { аналізу } \\
\text { параметрів }\end{array}$} & \multirow[t]{3}{*}{ Трудомісткий } \\
\hline 3.2 Стрес-тестинг & & & \\
\hline 3.3 GAP-аналіз & Процентний & & \\
\hline 4. Метод аналогій & $\begin{array}{l}\text { Кредитний, } \\
\text { ліквідності, } \\
\text { ринковий, }\end{array}$ & $\begin{array}{l}\text { Коли неможливо } \\
\text { застосувати інші } \\
\text { методи аналізу. } \\
\text { Висока } \\
\text { ефективність в } \\
\text { ординарних } \\
\text { умовах }\end{array}$ & $\begin{array}{l}\text { Важко створити } \\
\text { умови, у яких } \\
\text { повторився б } \\
\text { минулий досвід }\end{array}$ \\
\hline 5. Комбінований метод & $\begin{array}{l}\text { Кредитний, } \\
\text { ліквідності, } \\
\text { ринковий }\end{array}$ & $\begin{array}{l}\text { Синергетичний } \\
\text { ефект. Висока } \\
\text { ефективність в } \\
\text { ординарних } \\
\text { умовах та в } \\
\text { умовах кризи }\end{array}$ & $\begin{array}{l}\text { Трудомісткий, } \\
\text { потребує обробки } \\
\text { великого обсягу } \\
\text { статистичної, } \\
\text { бухгалтерської та } \\
\text { управлінської } \\
\text { інформації }\end{array}$ \\
\hline
\end{tabular}

* побудовано автором

Останній етап управління фінансовими ризиками - зменшення їх рівня включає у себе використання основних інструментів системи ризикменеджменту банку: страхування, хеджування, ліміти, диверсифікація, резерви.

Розглянемо кожний з цих інструментів. Страхування є одним з елементів передачі ризиків банку певним страховим компаніям, але, по-перше, не всі 
банківські ризики підлягають страхуванню, а по-друге, чим більший обсяг ризику перекладається на страхову компанію, тим вищим $є$ витрати на оплату відповідного страхового полісу. Тому одна 3 основних проблем управління фінансовими ризиками полягає в тому, щоб визначити, які ризики має сенс залишати в банку, здійснюючи додаткові витрати для їх зменшення, а які перекласти на страховика, роблячи додаткові витрати для оплати BBВ-полісу.

Другим інструментом передачі ризику є хеджування, під яким мається на увазі зменшення фінансових ризиків (в першу чергу ринкового) за допомогою похідних інструментів фінансового ринку: ф'ючерсів, форвардів, свопів та опціонів (табл. 3).

Таблиця 3

Похідні інструменти хеджування ринкового ризику*

\begin{tabular}{|c|c|c|c|}
\hline Назва & Характеристика & Переваги & Недоліки \\
\hline Форвард & $\begin{array}{l}\text { Угода щодо купівлі-продажу, коли розрив між } \\
\text { датою укладення угоди та датою проведення } \\
\text { обміну активами перевищує два робочих дні. } \\
\text { Ціна (курс), за якою (яким) буде здійснюватися } \\
\text { операція в майбутньому, фіксується в момент } \\
\text { укладання форвардного контракту. Форвардний } \\
\text { контракт є обов'язковим для виконання кожною } \\
\text { стороною. Форвардний контракт не є } \\
\text { стандартизованим, тобто може бути укладений } \\
\text { на будь-який строк та будь-яку суму, за } \\
\text { бажанням сторін }\end{array}$ & $\begin{array}{l}\text { Індивідуальний } \\
\text { характер укла- } \\
\text { дення угоди; } \\
\text { відсутність } \\
\text { комісійних; не } \\
\text { потребує } \\
\text { щоденного } \\
\text { переоцінювання } \\
\text { за поточним } \\
\text { курсом чи } \\
\text { ставками }\end{array}$ & $\begin{array}{l}\text { Низька } \\
\text { ліквідність } \\
\text { інструменту; } \\
\text { складність } \\
\text { пошуку } \\
\text { контрагента }\end{array}$ \\
\hline Ф'ючерс & $\begin{array}{l}\text { Угода, яка аналогічна форварду, але } \\
\text { відбувається за стандартизованими умовами: } \\
\text { здійснюється тільки на біржах, під їх } \\
\text { контролем, а форма і умови контрактів чітко } \\
\text { уніфіковані. Розрахунки щодо купівлі-продажу } \\
\text { ф'ючерсних контрактів здійснюються через } \\
\text { розрахункову палату біржі. }\end{array}$ & $\begin{array}{l}\text { Висока } \\
\text { ліквідність } \\
\text { інструменту, } \\
\text { гарантування } \\
\text { своєчасності і } \\
\text { повноти } \\
\text { платежів } 3 \text { боку } \\
\text { біржі }\end{array}$ & $\begin{array}{l}\text { Стандартні } \\
\text { умови угоди; } \\
\text { обмежена } \\
\text { гнучкість } \\
\text { щодо } \\
\text { термінів та } \\
\text { інших умов } \\
\text { контракту }\end{array}$ \\
\hline Опціон & $\begin{array}{l}\text { Угода, аналогічна форварду та ф'ючерсу, за } \\
\text { якою одній стороні - покупцеві опціону - } \\
\text { надається виключне та безумовне право } \\
\text { вибору здійснювати операцію купівлі-продажу } \\
\text { чи ні. Друга сторона - продавець опціону - } \\
\text { зобов'язана виконувати рішення покупця } \\
\text { опціону і не має права відмовитися від своїх } \\
\text { зобов'язань. Розрізняють опціон кол - опціон, } \\
\text { який надає право купувати базовий актив, та } \\
\text { опціон пут, який надає право продавати } \\
\text { базовий актив. Розрізняють також } \\
\text { американський опціон - угода, яка може бути } \\
\text { виконана в будь-який момент протягом усього } \\
\text { строку ії дії, та європейський опціон, який } \\
\text { може бути виконаний тільки в кінці строку дії }\end{array}$ & $\begin{array}{l}\text { Можливість } \\
\text { вибору під час } \\
\text { прийняття } \\
\text { рішення про } \\
\text { виконання } \\
\text { опціону; } \\
\text { обмеження } \\
\text { ризику покупця } \\
\text { величиною } \\
\text { опціонної премії, } \\
\text { яка визначається } \\
\text { в момент укла- } \\
\text { дання угоди }\end{array}$ & $\begin{array}{l}\text { Висока } \\
\text { вартість; } \\
\text { стандартні } \\
\text { умови } \\
\text { біржових } \\
\text { опціонів }\end{array}$ \\
\hline $\begin{array}{l}\text { Своп } \\
\text { проце- } \\
\text { нтної }\end{array}$ & $\begin{array}{l}\text { Контрактна угода між двома сторонами, } \\
\text { відомими як учасники свопу, про обмін } \\
\text { потоками грошових коштів, які розраховані за }\end{array}$ & $\begin{array}{lr}\text { Низька } & \text { вартість; } \\
\text { висока } & \text { розви- } \\
\text { неність } & \text { ринку }\end{array}$ & $\begin{array}{l}\text { Високий } \\
\text { ризик } \\
\text { невиконання }\end{array}$ \\
\hline
\end{tabular}




\begin{tabular}{|c|l|l|l|}
\hline ставки & $\begin{array}{l}\text { різними ставками, але виходячи з однієї суми, свопів } \\
\text { відомої як умовна сума. Як правило, один } \\
\text { потік коштів розраховуєтья за фіксованою } \\
\text { ставкою, а інший - за плаваючою ставкою }\end{array}$ & $\begin{array}{l}\text { контрагентом } \\
\text { своїх } \\
\text { зобов'язань }\end{array}$ & \\
\hline $\begin{array}{c}\text { Валютний } \\
\text { своп }\end{array}$ & $\begin{array}{l}\text { Одночасне укладання спот та протилежної } \\
\text { форвардної угоди. Іноземна валюта, придбана } \\
\text { згідно з угодою спот, знову продається після } \\
\text { закінчення певного проміжку часу, і, } \\
\text { відповідно, валюта, що продається згідно з } \\
\text { угодою спот, після закінчення певного } \\
\text { проміжку часу купуєтья знову. Обидві угоди } \\
\text { укладаютья з одним і тим самим партнером, } \\
\text { при цьому курси, дати валютування та способи } \\
\text { платежу встановлюються в момент укладання } \\
\text { угоди }\end{array}$ & \\
\hline$*$
\end{tabular}

* побудовано на основі [10]

Зменшити фінансові ризики можна також за допомогою диверсифікації банківських продуктів або бізнес-напрямків. Приклади диверсифікації: збільшення числа видів цінних паперів в портфелях банку, кредитування за різними секторами економіки, реалізація декількох бізнес-проектів одночасно.

Диверсифікація може бути доповнена встановленням лімітів, що надає можливість банку обмежити величину відкритої ризикованої позиції (табл. 4).

Таблиця 4

\section{Основні види лімітів за фінансовими ризиками*}

\begin{tabular}{|c|l|}
\hline Вид фінансових ризиків & \multicolumn{1}{|c|}{ Вид ліміту } \\
\hline \multirow{2}{*}{ Кредитний } & Ліміти окремих контрагентів \\
\cline { 2 - 2 } & Ліміти географічної концентрації \\
\cline { 2 - 2 } & Ліміти галузевої концентрації \\
\hline Ліквідності & Ліміти на кумулятивні розриви ліквідності \\
\hline \multirow{5}{*}{ Ринковий } & $\begin{array}{l}\text { Ліміти на чутливість вартості портфелів до зміни ставок } \\
\text { дохідностей окремо за валютами }\end{array}$ \\
\cline { 2 - 2 } & $\begin{array}{l}\text { Ліміт на загальну чутливість до коливання процентних } \\
\text { ставок }\end{array}$ \\
\hline & Ліміти на відкриті валютні позиції за кожною валютою \\
\cline { 2 - 2 } & Ліміт на загальну відкриту валютну позицію \\
\hline
\end{tabular}

* побудовано автором.

Формування резерву - останній інструмент зменшення банківських ризиків. Основною проблемою при створенні резерву є оцінка потенційних наслідків ризиків.

У відповідності до чинного законодавства кожний банк має формувати резерви за активами та за наданими фінансовими зобов’язаннями (табл. 5).

Таблиця 5

Формування резервів за фінансовими ризиками банку*

\begin{tabular}{|c|c|c|}
\hline Вид резерву & Формула розрахунку & Пояснення \\
\hline $\begin{array}{lr}\text { Резерв } \\
\text { кредитом на } \\
\text { iндивідуальній } \\
\text { основі }\end{array}$ & Рінд = БВк - ТВк & $\begin{array}{l}\text { Рінд - сума резерву за кредитом; БВк - } \\
\text { балансова вартість кредиту; ТВк - } \\
\text { теперішня вартість попередньо } \\
\text { оцінених майбутніх грошових потоків } \\
\text { за кредитом }\end{array}$ \\
\hline
\end{tabular}




\begin{tabular}{|c|c|c|}
\hline $\begin{array}{l}\text { Резерв } \\
\text { кредитами } \\
\text { овердрафт } \\
\text { кредитними } \\
\text { лініями }\end{array}$ & РК=БВа-(Зк х (1-ПРК)+В3 х k) & $\begin{array}{l}\text { Рк - сума резерву за кредитом; Бва - } \\
\text { балансова вартість кредиту; Зк - борг за } \\
\text { кредитом овердрафт та кредитними } \\
\text { лініями; ПРк - показник ризику } \\
\text { кредиту; Вз - вартість забезпечення; k - } \\
\text { коефіцієнт ліквідності забезпечення }\end{array}$ \\
\hline $\begin{array}{l}\text { Резерв за групою } \\
\text { фінансових активів }\end{array}$ & $P_{2} p=\sum_{i=1}^{j}$ БBai $-\sum_{i=1}^{j} 3 a i \times\left(1-\Pi P_{2} p\right)$ & $\begin{array}{l}\text { Ргр - сума резерву; БВа - балансова } \\
\text { вартість за групою фінансових активів; } \mathrm{j} \\
\text { - загальна кількість кредитів у групі } \\
\text { фінансових активів; і - порядковий } \\
\text { номер кредиту в групі фінансових } \\
\text { активів; За - борг за активом на дату } \\
\text { розрахунку резерву; ПРгр - показник } \\
\text { ризику групи фінансових активів }\end{array}$ \\
\hline $\begin{array}{l}\text { Резерв за цінним } \\
\text { папером }\end{array}$ & Рцп = БВцп - ТВцп & $\begin{array}{l}\text { Рцп - сума резерву; БВцп - балансова } \\
\text { вартість цінного папера; ТВцп - } \\
\text { теперішня вартість попередньо } \\
\text { оцінених майбутніх грошових потоків } \\
\text { за цінним папером }\end{array}$ \\
\hline $\begin{array}{l}\text { Резерв за наданим } \\
\text { фінансовим } \\
\text { зобов'язанням }\end{array}$ & Рфз $=$ Ск $-($ Св + Взфз х k) & $\begin{array}{l}\text { Рфз - сума резерву; Ск - сума коштів, } \\
\text { необхідних для виконання банком } \\
\text { фінансового зобов'язання; Св - сума } \\
\text { отриманої банком винагороди } \\
\text { урахуванням амортизації); Взфз - } \\
\begin{array}{l}\text { вартість отриманого забезпечення; k - } \\
\text { коефіцієнт ліквідності забезпечення }\end{array}\end{array}$ \\
\hline
\end{tabular}

* побудовано на основі [11]

Банк використовує сформований резерв за активами у тому випадку, коли актив віднесено до найнижчої (безнадійної) категорії якості (рішення про списання безнадійної заборгованості за активом приймається правлінням банку).

Зазначимо, що управління фінансовими ризиками за центрами відповідальності потребує відповідних змін облікової політики банку та корпоративного управління. Результатом таких змін може стати не тільки зменшення розміру фінансових ризиків, а й оптимізація продуктового ряду i підвищення прибутковості банку.

Висновки. Банківська діяльність пов 'язана 3 певними видами фінансових ризиків: кредитний, ринковий, ризик ліквідності. Вони виникають в процесі здійснення основних активно-пасивних операцій кредитної установи. Управління фінансовими ризиками є процесом, що охоплює методи та інструменти з ідентифікації, оцінки, планування та зменшення ризиків задля забезпечення стійкого розвитку банку в ординарних та кризових умовах.

Здійснювати етапи управління фінансовими ризиками доцільно за центрами відповідальності банку, які виокремлюються за бізнес-напрямком та видом фінансового ризику, що виникає в процесі реалізації цього бізнеснапрямку (здійснення певних активно-пасивних операцій). Керівники таких центрів відповідають не тільки за дієвість інструментів оцінки та зменшення 
розміру фінансових ризиків, а й за виконання показників бюджетних та стратегічних планів банку, у складанні яких вони також беруть участь.

Володіючи повною інформацією стосовно специфіки функціонування очолюваного центру відповідальності в ординарних та в кризових умовах, керівники центрів мають можливість визначити та реалізувати найбільш дієві інструменти зменшення фінансових ризиків: страхування, хеджування, встановлення лімітів, проведення диверсифікації, формування резервів.

Наукова новизна проведеного дослідження полягає у формуванні методичного підходу виокремлення центрів відповідальності банку, що грунтуються не стільки за бізнес-напрямками сегменту, скільки на аналізі фінансових ризиків, які виникають в процесі здійснення активно-пасивних операцій сегменту. Практичне значення проведеного дослідження сформоване визначенням методів та інструментів оцінки і зменшення фінансових ризиків за центрами відповідальності банку. Перспективи подальших наукових розробок за даним напрямом полягають у досліджені специфіки ідентифікації, оцінки, планування та зменшення фінансових ризиків за центрами відповідальності банку в ординарних та в кризових умовах.

\section{Література:}

1. Грюнинг Х. Ван. Анализ банковских рисков. Система оценки корпоративного управления и управления финансовым риском / Х. Ван Грюнинг, С. Брайонович-Братанович. - М. : Весь Мир, 2004. - 150 с.

2. Д'яконова I. Система управління банківськими ризиками / I. Д'яконова // Вісник СумДУ. Серія Економіка. - 2008. - № 2. - С. 48-57.

3. Івасів І. Б. Лімітування ризику ліквідності банку на основі стрес-тестування / І. Б. Івасів, О. Ю. Фуксман // Економіка та держава. - 2014. - №11. - С. 85-89.

4. Роуз П. Банковский менеджмент / П. Роуз ; пер. с англ. со 2-го изд. - М. : Дело, 1997. $-768 \mathrm{c}$.

5. Вовк В. Сутність і зміст антикризового управління діяльністю комерційного банк [Електронний ресурс] / В. Вовк // Коммунальное хазяйство городов : науч.-техн. сб. - Режим доступу : http:www.eprints.ksame.kharkov.ua.

6. Коваленко В. В. Розвиток науково-методичних підходів до оцінювання проблемних кредитів банку як складової системи управління ними / В. В. Коваленко, Т. М. Болгар // Актуальні проблеми економіки : Науковий економічний журнал. - 2013. - № 10. - С. 185 195.

7. Косова Т. Д. Система управління кредитними ризиками банку / Т. Д. Косова, Є. М. Поздняков // Торгівля і ринок України. - 2013. - Вип. 35. - С. 201-211.

8. Примостка Л. О. Банківські ризики. Теорія та практика управління: монографія / Л. О. Примостка. - К. : КНЕУ, 2008. - 450 с.

9. Хуторна М. Е. Бюджетування як інструмент управління банком [Електронний ресурс] / М. Е. Хуторна, О. М. Бартош // Ефективна економіка. - 2013. - № 4. - Режим доступу : http://www.economy.nayka.com.ua/?op=1\&z=1942

10 Методичні вказівки 3 інспектування банків «Система оцінки ризиків» [Електронний ресурс] : Постанова Правління НБУ від 15.03.2004 p. № 104. - Режим доступу : http://zakon2.rada.gov.ua/laws/show/v0104500-04.

11. Про затвердження Положення про порядок формування та використання резерву для відшкодування можливих витрат за активними банківськими операціями [Електрон. ресурс] : Постанова Правління Національного банку України № 23 від 25.01.2012 р. - Режим доступу : http://zakon4.rada.gov.ua/laws/show/z0231-12. 